\title{
Prospects of Musical Computer Technologies Application for Studying, Preservation and Translation of Musical Folklore (on the Example of the Russian Far East)
}

\author{
Svetlana V. Mezentseva ${ }^{1}$ \\ ${ }^{1} \mathrm{PhD}$ in Art History, Associate Professor, Member of the Union of Composers of Russia, Head of the \\ Department of Art History, Musical-Instrumental and Vocal Art of the Khabarovsk State Institute of Culture, \\ Khabarovsk, Russia
}

\begin{abstract}
The article analyzes the problems of collecting and processing folklore materials, considers contemporary information resources and technologies as a means of preserving and transmitting musical folklore. The Far East is noted as a unique ethnic region, on the territory of which carriers of completely different traditional cultures live. It is noted that traditional folklore is rapidly disappearing, native speakers of languages and culture are passing away. The inevitability of the introduction of information technologies in the musical environment, the prospects of music computer technologies (MCT) as an instrument of developing, transmitting and preserving of musical culture is recognized. The problems of the disappearance of traditional cultures are considered from the position of the need for the early introduction of the MCT in the practice of researchers of musical folklore. The authors mark the necessity of collection of unique samples of traditional musical creative work, study and comprehension of the most valuable collected materials, work on decoding of musical samples. The author comes to the conclusion about the possibility of MCT to play a significant role in developing, transmitting and preserving musical culture of the Russian Far East, as well as the preserving, developing and promoting the traditional cultural heritage of multinational Russia
\end{abstract}

Keywords: music computer technologies, traditional musical culture, musical culture of the Russian Far East, intercultural communication, transmitting of musical culture.

\section{Introduction}

The traditional culture of the Russian Far East is vast cultural heritage. Extant elements of rites, examples of artistic and musical creativity, household items, and tools testify the natives' rich culture. The peculiarity of the material and spiritual culture of the indigenous peoples of the Russian Far East is the abundance of common features, as these peoples had neighbourhood, led identical lifestyles and shared a similar worldview. Close contacts of aborigines led to a synthesis of cultures, ethno and cultural genesis.

At present, in connection with vanishing of samples of the Russian Far East aborigines' musical culture, there is a challenge to preserve folklore. Traditional folklore is rapidly disappearing; native speakers are passing away. Globalization tends to be a threat to distinctive traditional cultures making irreparable losses. In the context of globalization, traditional culture is considered inappropriate and back off, but we must understand that it contains traditional human values and the experience of generations.

\section{Musical folklore of the Russian Far East at the present stage}

The Russian Far East aborigines' life and culture have changed. It has become noticeable since the end of the XIX century because this historical period is associated with the active development of the Russian Far East. New living conditions have caused the inevitable routine transformation. Gradually, traditional thinking, worldview and ritual culture have gone to the past. The musical culture has also changed through the time. Recently, bear festival, shamanic rites, and rituals associated with the cult of Gemini, have almost disappeared. Most of the information about aboriginal life and culture can be found in books, few audio and video recordings. There are fewer and fewer authentic carriers of traditional folklore. Change in the historical and socio-cultural conditions of the existence of the Russian Far East aborigines and urbanization have influenced the formation 
and development of new content of musical folklore traditional genres greatly, as well as initiated the birth of new genres and intonation types.

Nowadays the musical folklore of the indigenous peoples of the Russian Far East acts in national folk groups where musical instruments have a second birth. In the 20th century, traditional musical instruments are hardly ever used as ritual attributes. They accompany dances, amateur performances, children's games and sometimes songs. Despite complete or partial disappearance of cults, rites (or their transformation and rebirth) and samples of musical folklore, much is still stored in the elderly's memory and subconscious. The most important task of modern science is preservation, study and translation of these samples.

One of the "alternative" ways of aboriginal musical instruments functioning is professional composers' work where peculiar tone qualities of traditional instruments are. An invaluable resource of ethnic musical materials of the Russian Far East is the works by professional composers N. N. Mentser, Yu. Ya. Vladimirov, B. D. Napreev and others who have contributed to the preservation and revival of national musical folklore. Their works based on distinctive modal, swing, textural regularities and intonation features of the Far Eastern folklore have contributed to the original synthesis of traditional and European intonation cultures. The most precious is the works by N. N. Mentser who used not only direct quotes of native songs and instrumental tunes but also the method of folklore re-intonation. One can use excerpts from major works ("Evenk Rhapsody", "Nivkh stories", "Dance games", "Ulchi” suites, "Hojo", "Catoca", "Amur fragments", "Reindeer race" symphonic picture), vocal genres ("Nanai fishing", "Kayrak", "Udege girls", "Boat", "Beloved region”) and etc.

\section{Music computer technologies role in the processes of folklore recording, preservation and transmission}

The inextricable link between material, technical and technological in culture poses a number of problems for modern research, among which are, in particular, identification of technologizing opportunities and limits in modern culture, the role of the music computer technologies (MCT) in music education and composing, as well as in the development, translation and preservation of traditional musical culture. It is known that the most stable part of culture is tradition that collaborates with the innovation constantly and inevitably and to a certain extent is being enriched by them.

The development of modern information technologies opens up new opportunities for collecting, recording, preserving and transferring folklore funds. At the present stage of technical progress, it is possible to store and transmit (broadcast) the aborigines' endangered musical folklore. The most perfect type of sound recording is digital. Digitized recording can be broadcast with no loss of quality. Today, library archival collections are computerized, materials are digitized, electronic catalogues and databases are created, and new methods of collecting and preserving folklore are being developed. Modern processes in this field lead to the need to develop new methods and technologies for handling folklore samples.

Since the middle of the XX century electronic music has created powerful means of music expression, penetrating not only into the space of academic genres, but also in the sphere of theater and cinema music. Semantic and morphological properties of musical compositions created with the help of MCT can be considered as abstract levels of musical culture developed in the conditions of high - tech information creative sphere: virtual educational and creative environment in the field of culture [6].

It should be noted that being a phenomenon of cyber culture the idea of virtuality, which gets its logical and artistic understanding and embodiment in musical creativity of various genres and styles, is determined with the inclusion of information technologies in the sphere of musical culture and is interpreted as an artificially created medium [1]. Elements of any musical text, being a form of substitution of psychological phenomena and emotional experience, act as an instrument of virtualization of musical culture [4; 7]. This statement can be attributed to the various systems of analysis, recognition and creation of musical text, which contain information about intonation that is one of the most important elements of musical speech, which, in particular, determines the need to build an intonation catalog (see in more detail [2]) of music of the peoples of the world. 
With the development of MCT, musicians have been able to create more and more high-quality phonograms. Means of digital filtering and processing of phonograms $[5 ; 6]$ give practically unlimited opportunities for creating elements of sounding defined only by artistic and aesthetic needs of folklore carriers and researchers, musicians-folklorists and a group of highly skilled professionals and listeners.

In the situation of interaction and interpenetration of different cultures at cross continental, cross ethnic and inter-state levels, modern means of cultural transmission are of particular significance. Today, the real possibility of online transmission of any format information opens up new horizons for adequate data transmission and accelerates the "exchange processes" within the framework of cultural dialogue problem repeatedly.

UNESCO Universal Declaration on Cultural Diversity November, 2, 2001 considers that "the process of globalization, facilitated by the rapid development of new information and communication technologies, though representing a challenge for cultural diversity, creates the conditions for renewed dialogue among cultures and civilizations" [3].

The emergence and development of modern computer recording studio as means of musical creativity and the modern musical culture phenomenon [5] contains elements that allow to preserve the traditions and mechanisms of cultural inheritance in terms of historical continuity and translation of cultural values and meanings today.

\section{Conclusion}

Modern Internet resources make it possible to provide access to information within the entire world scientific community. In our time, researchers should set themselves new tasks. It is necessary to explore the resources and possibilities of using modern information and communication technologies, the latest music computer technologies for collecting, adequate processing, preservation, transmission and retranslation of traditional musical culture, as well as understanding their role and importance in the field of cultural dialogue and intercultural communication.

MCT can play a crucial role in the process of mastering, broadcasting and preserving the Russian Far East musical culture, as well as preserving, developing and popularizing the traditional cultural heritage of multinational Russia. Here and now, MCT act as a new kind of accumulation and translation of music knowledge, as means of the basic data processing. Digitizing of musical heritage collections and traditional culture preservation and development are of national value.

The inextricable link between the material, technical and technological in culture poses a number of problems for modern research that is identification of technologizing opportunities and limits in modern culture, the preservation and development of tolerance in dialogues of cultures within the digital educational space, the role of the MCT in music education and compositing, etc.

\section{References}

[1] Aliyeva, I. (2014). Azerbaijani Modes: Their Evolution and Manifestation in Traditional and European Genres (Cognitive Approach) / Eighth European Music Analysis Conference. Leuven, Belgium, 17th-20th September, 2014.

[2] Alieva, I. G., Gorbunova I. B. Concerning the project of intelligent system of cataloguing and analysing of the world's peoples music. Society: Philosophy, History, Culture. 2016, no. 9, pp. 105-108.

[3] UNESCO Universal Declaration on Cultural Diversity. Adopted on 2 November 2001 by the General Conference of the United Nations Educational, Scientific and Cultural Organization. URL: http://www.un.org/ru/documents/decl_conv/declarations/cultural_diversity.shtml

[4] Gorbunova, I.B., Information Technologies in Music, vol. 3: Music computer: course book, Saint Petersburg: Publishing house of the Herzen State Pedagogical University of Russia, 2011, 411 pp. 
[5] Gorbunova, I. B., "Computer recording studio as an instrument of musical creativity and the phenomenon of musical culture", Society: Philosophy, History, Culture, no. 2, pp. 87-92, 2017.

[6] Gorbunova, I. B., "Music computer technologies and DIGITAL HUMANITIES", Contemporary Music Education 2015, Proceedings of the XIV International Scientific and Practical Conference, ed. Irina B. Gorbunova, pp. 29-34, vol. 1, Saint Petersburg: Publishing house of the Herzen State Pedagogical University of Russia, 2015.

[7] Gorbunova, I. (2018). "New Toll for a Musician". 15th International Conference on Education, Economics, Humanities and Interdisciplinary Studies (EEHIS-2018), Paris (France), June 20 - 21, 2018, pp. 144 - 150.

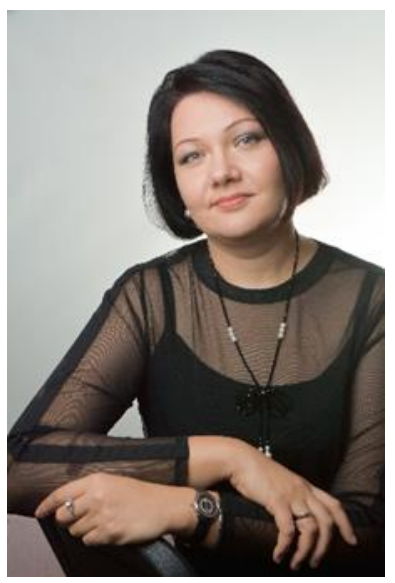

Mezentseva Svetlana Vladimirovna was born in Moscow February 5, 1977.

Background: Music expert, Teacher, Musicologist, the Far Eastern State Academy of Arts, Vladivostok, Russia, 2001. Maintained a thesis "Russian Far East Tungus-Manchurians ritual culture instrumental music genre typology " for a degree of PhD in Art History, the St. Petersburg Humanitarian University of Trade Unions, St. Petersburg, Russia, 2007; Associate Professor, the Khabarovsk State Institute of Arts and Culture, Khabarovsk, Russia, 2008; Music expert, Member of the "Union of Composers of Russia", 2017.

She has been working as the Head of the Department of Art History, Musical-Instrumental and Vocal Art of the Khabarovsk State Institute of Culture, Khabarovsk, Russia since 2000.

Publications: Russian Far East Tungus-Manchurians ritual culture instrumental music (problems of genre typology). Scientific monograph. Khabarovsk, Russia: Publishing house HGIC, 2017. 139 p; "EastWest: intercultural communication in educational space of universities". World of Science, Culture and Education, 2017, no. 6 (67), pp. 339-341; "Overcast-oriented technologies as a new method of culture interaction in the field of higher musical-pedagogical education". Pedagogy of Art: network electronic scientific journal, 2018, no. 5. URL: http://www.art-education.ru/pedagogika-iskusstva-38

Mrs. Mezentseva, PhD in Art History, Associate Professor, Member of the Union of Composers of Russia, Head of the Department of Art History, Musical-Instrumental and Vocal Art of the Khabarovsk State Institute of Culture, Khabarovsk, Russia. 